\title{
Project-Based Museum-School Partnerships in Support of Meaningful Student Interest- and Equity-Driven Learning Across Settings
}

\author{
Jrène Rahm, Université de Montréal \\ jrene.rahm@umontreal.ca
}

\begin{abstract}
In this paper, I focus on two teachers' experiences with project-based museum-school partnerships that they participated in with their students. The partnerships implied collaborations with scientists, archaeologists, and artists in their classrooms, as well as informal educators from museums tied to the projects. The projects made new ways to engage in student interest-driven cross-setting learning available to the students and teachers. The participating teachers seemed to suggest a need to move towards the co-design of such partnerships in the future with youth-a process that could be initiated in teacher education programs or supported through innovative approaches to professional development.
\end{abstract}

Keywords: Museum-school partnership; project-based learning; cross-setting learning; archaeology education; science education; arts education, robotic.

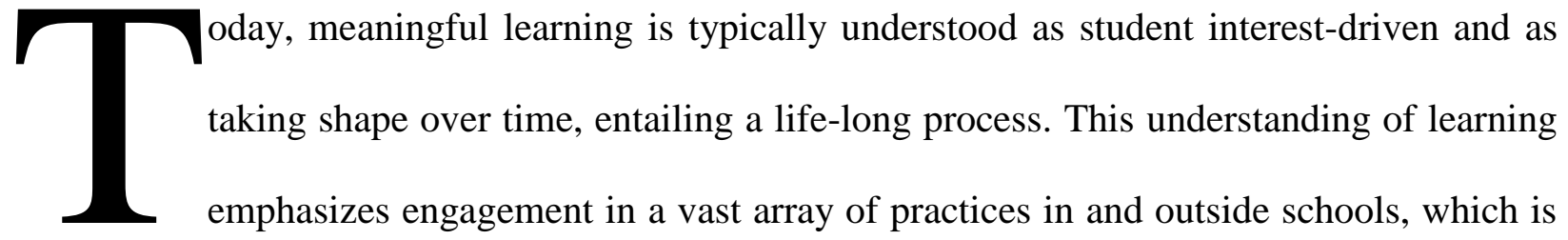

often referred to as cross-setting learning or life-wide learning (Banks et al., 2006). This vision has led to a renewed interest in documenting how teachers and informal educators, such as practicing scientists and artists, and informal learning institutions, like arts museums, science centres, and their informal educators work together to engage students in meaningful projectbased learning in the sciences and the arts (Bevan \& Dillon, 2010; Lemonchois, 2015, 2010). The kinds of learning opportunities partnerships among diverse educators and institutions support and how such partnerships can be initiated and sustained over time are areas with unique challenges that require further research (Kisiel, 2014; Russell, Knutson, \& Crowley, 2013). We live in a fractured landscape where quality formal and informal learning resources are not equally accessible to all. Thus, researchers committed to equity have started to imagine what 
learning ecologies could look like that meet the needs of diverse learners by bringing museums and schools together in innovative ways that build on student interest (American Alliance of Museums, 2014).

In this article, I draw upon a study of museum-school partnerships organized and offered through the administrative constituency known as the Supporting Montreal Schools Program (SMSP), which was incepted in 1996 by the Ministry of Education of Quebec. The SMSP was created to promote the educational success of disadvantaged students in Montreal, Canada (Archambault \& Richer, 2014; MEQ, 2004). One of the program's components was intended to make cultural resources more widely accessible through subsidized mandatory fieldtrips to museums for all students in the target schools. Additionally, that measure offered innovative projects to teachers and students interested in more sustained engagement with informal educators such as scientists and artists, as well as informal educators from partner institutions. I focus on the teachers' and students' engagement with informal partnership institutions. I do this by drawing on a two-year qualitative study, with observations of partnership projects and teacher interviews pursued during the academic school year of 2004-2005, and follow-up interviews with teachers in 2006. The study focused on seven specific partnership projects in the sciences, namely in astronomy, space sciences, archaeology, entomology, ornithology, paleontology, and robotics, put in place by SMSP. All partnerships implied residencies of scientists, archaeologists, and artists in classrooms who worked with the teachers. Additionally, the partnerships included educational activities offered by informal educators in partner institutions, specifically, museums and science centers. Most of the partnerships culminated with the exhibition of student projects in the museums and science centers. 
In prior research, I explored how these partnerships became a means to reengage students in learning associated with schools and how the projects became locally meaningful and empowering through the work of the students and teachers (Rahm, 2006, 2008, 2012). Building on this work, in this paper, I focus on two experienced teachers who participated in organized partnership projects as part of SMSP over a period greater than four years and who took part in our study. I discuss the ways in which these partnership projects supported student interestdriven cross-setting learning and made museum and community resources accessible to all participants (i.e. teachers and students) in new and transformative ways.

\section{Methods}

I engaged in a content analysis of four semi-structured interviews conducted with two sixth-grade elementary school teachers, Mary and Colette, at the end of the school year in 2005. These interviews followed our in-depth observational study of the partnerships they engaged in that year. Follow-up interviews were conducted in the spring of 2006. Mary participated in a project in robotics and then the creation of an oversized storybook in collaboration with specialists and informal educators, and Colette pursued a project in archaeology, followed by Arrimage - a project that integrated the arts with the sciences, in collaboration with artists and informal educators. The following summarizes the projects that Mary and Colette engaged in:

Table 1. Summary of activities and partners in each project.






\begin{tabular}{|c|c|}
\hline $2005-2006$ & du Québec \\
\hline Archaeology & - Archaeologist visits the classroom four times \\
\hline Colette & - Students study archaeology with Colette \\
\hline Year & - Visit to the Musée de Lachine, directed by archaeologist, informal educator \\
\hline 2004-2005 & and Colette \\
\hline & $\begin{array}{l}\text { - Archaeological dig under direction of the archaeologist and informal } \\
\text { educator at same site }\end{array}$ \\
\hline Arrimage & - Exploration of the theme "Between the Earth and the Sky" with informal \\
\hline Art/Science & educators at the Centre des sciences de Montréal \\
\hline Colette & - Exploration of the theme "Between the Earth and the Sky" with informal \\
\hline Year & educators at the Musée d'art contemporain de Montréal \\
\hline 2005-2006 & $\begin{array}{l}\text { - Creation of an artwork under the guidance of an artist in the classroom } \\
\text { - Exhibit of the artwork at the Musée d'art contemporain de Montréal and } \\
\text { later at the Centre des sciences de Montréal }\end{array}$ \\
\hline
\end{tabular}

\section{Robotics and a giant storybook: Mary's pedagogial footing and reflections}

What an amazing project! How proud we were to contemplate the results and to present them to the visitors. It's a project that got my students actively involved from the beginning given its inclusionary nature. To work with robots immediately got their attention. To work with aïbo was tempting too. The assembling and programming of the robots posed a real challenge and appeared to entail the kind of problem solving typically reserved for technology experts. Those with less affinity in technology had the opportunity to be involved in the construction of a city, making the project meaningful to all. To know that our city would then be presented in a public space as prestigious as the Centre des sciences de Montréal really helped maintain the motivation over time. We could not just bail out either, we had an obligation to the organizers of the project to deliver, which got us through the last weeks during which stress mounted and lack of time became a challenge. It gave us the energy and creativity to keep going and to finish the project. (Interview, 2005, Mary, Teacher) 

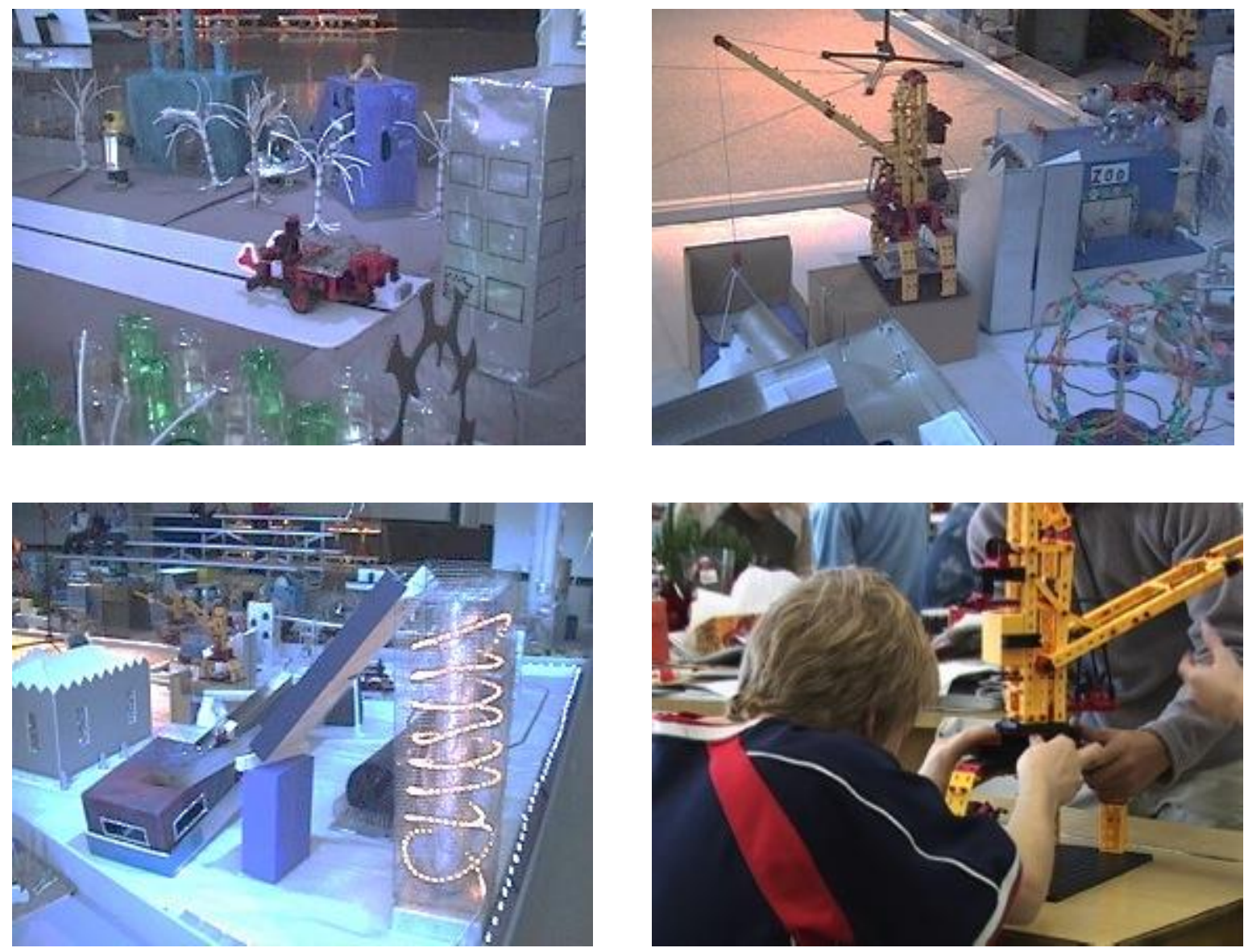

Figure1. Robot City, Exhibited at Science Center

Mary was one among six elementary school teachers who participated in a partnership project between her school and the science centre. Her involvement led to the joint production of an exhibit in which five robots navigated an imaginary part of a city that the class constructed from recycled materials. Mary sought out the project in robotics knowing that her students would greatly enjoy it even though she did not have an affinity towards the subject. Mary stated: "me and robotics, I am a zero in it, I have no interest in it, but, the students, they don't know that, they think I love robotics" (Interview, 2005). Her experience in that particular school had taught her that 'it's important to start with the children's interests and then get them to do French, math, and science, but you have to start building a link with the child, otherwise nothing works" 
(Interview, 2005). She added, "school for them is paper, pencil, worksheets, and books, and suddenly, we do something different, it shows them that there is more out there in real life" (Interview 2005). Given the students' interest in robotics, the project was a means to get her students more deeply engaged with technology (e.g. design and construction of robot, programming). Some students who were initially disengaged also volunteered to present the project in the science centre which came as a surprise.

The oversized book project (Figure 2) began with a collaboratively created story with a writer and Mary's students, which was a new process for Mary. The writer asked students to work on components of the story in teams. They then convened and discussed ways to integrate the components. The writer offered advice regarding how best to ensure that the stories were compelling. Designing the oversized book, which was made using fabric and various sewing techniques with the help of a professional seamstress, turned out to be challenging. It was not something all of the students were interested in. The class also had to prepare a presentation to be given at the exhibit of the book at the Le Musée des Maitres et Artisans du Québec. The presentation had to entice the visitors to read the book. Mary was disappointed by her students' level of engagement as they practiced the presentation. However, Mary noted that once they were in the museum for the actual presentation, "they all spoke loud and clear, it was a very nice presentation, I am still surprised, never anticipated that!” (Interview, 2006). 

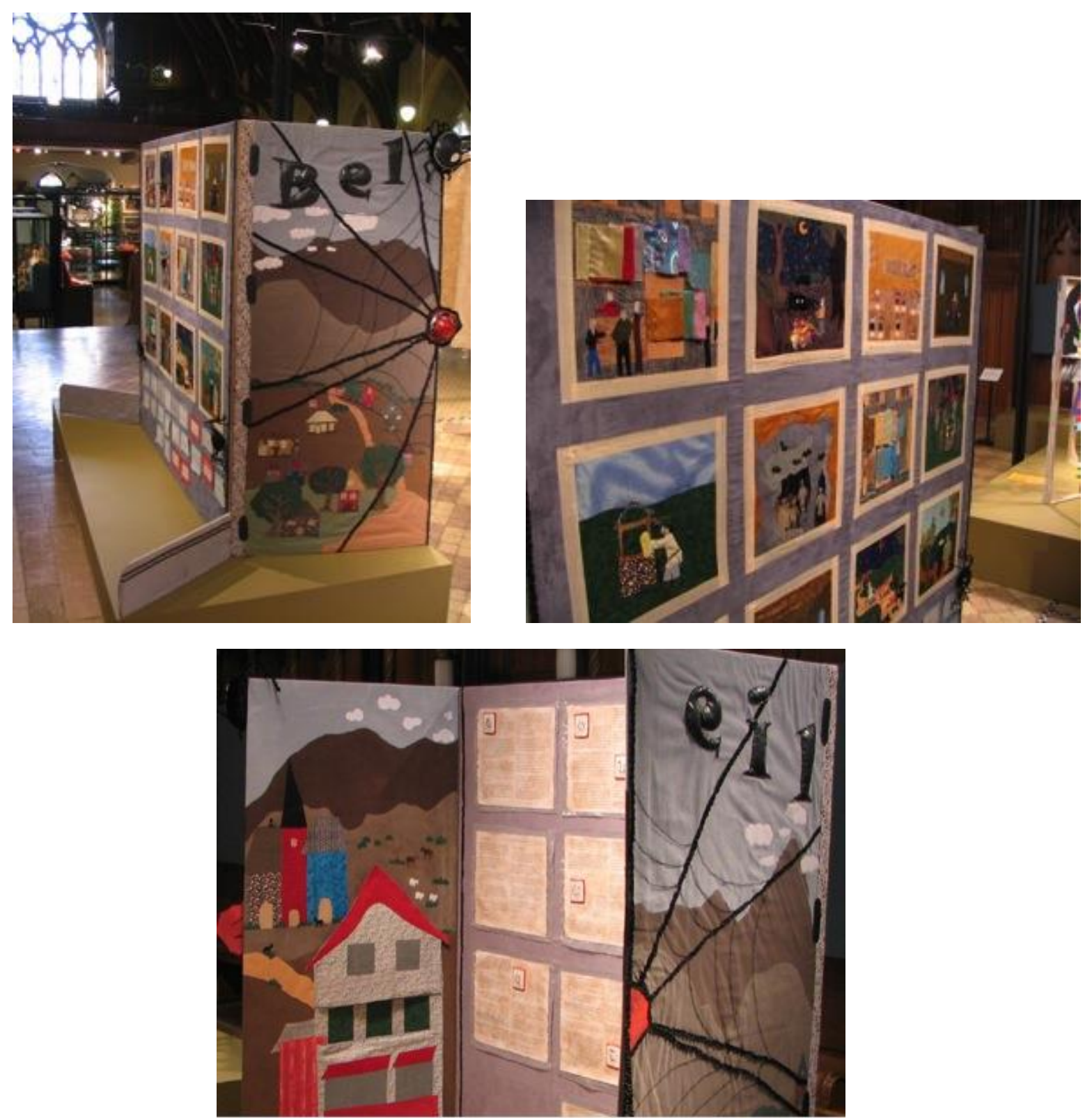

Figure 2. Title of Giant Book Project: "Spiders, Spinners of Excellence, Invaded the Fabrics of this Work", Exhibit 2006.

Mary highly valued the exhibits of both partnership projects: "The thing that is most important is the fact that the students get to exhibit their work in a public space" (Interview, 2006). It is different from the usual practice of presenting projects to parents at school, "it is a notch above, professionals and everyday-like people or the world will see it!" (Interview, 2006). The fact that the museum offered to exhibit the students' work also drew Mary to the projects, 
given how challenging it would have been for her to organize that herself. Reflecting upon both projects and her students' participation, Mary noted, "When you offer them activities that have nothing to do with writing in notebooks or doing exercises, you also realize that they have all kinds of talents. They realize themselves that they are talented, it makes students value school in new ways" (Interview, 2006).

Yet, Mary also critiqued the approach taken by SMSP in that "they offer projects designed by teachers and professionals, there is an important difference between a project designed by a teacher for the students and putting students in a project" (Interview, 2006). Both offer opportunities for creativity but only the latter builds on students' interests and is driven by student voice. Mary was concerned that especially her second-year project, the oversized book, did not get all of her students engaged given its narrow focus on writing and sewing. The project in robotics was more open-ended given its complexity, making it more inclusive. Some students constructed robots, others programmed robots, and still others designed the village. Given the many roles students could take with the project, project ownership and student agency were supported. Yet, Mary still felt more could have been done to make the museum-school partnership projects more inclusive of student voice.

\section{Colette's engagement in archaeology, science, and the arts}

Once a child has a clear goal and understands why it is worthwhile to pursue that goal, when there is consistency, it becomes doable. That became clear to me as I struggled to understand in what ways the projects by SMSP were student centred. Somehow, once I saw the artist arrive with all the materials that were then layed out on two tables for the students to work with, I knew it would work out. I could tell my students to do what they wanted with the materials and the arts piece we were working on, it was like a dream! And 
having an artist work with us was like a miracle, that never happens in this school, we should have artists, musicians, and other experts come more often. (Interview 2006, Colette, Teacher)
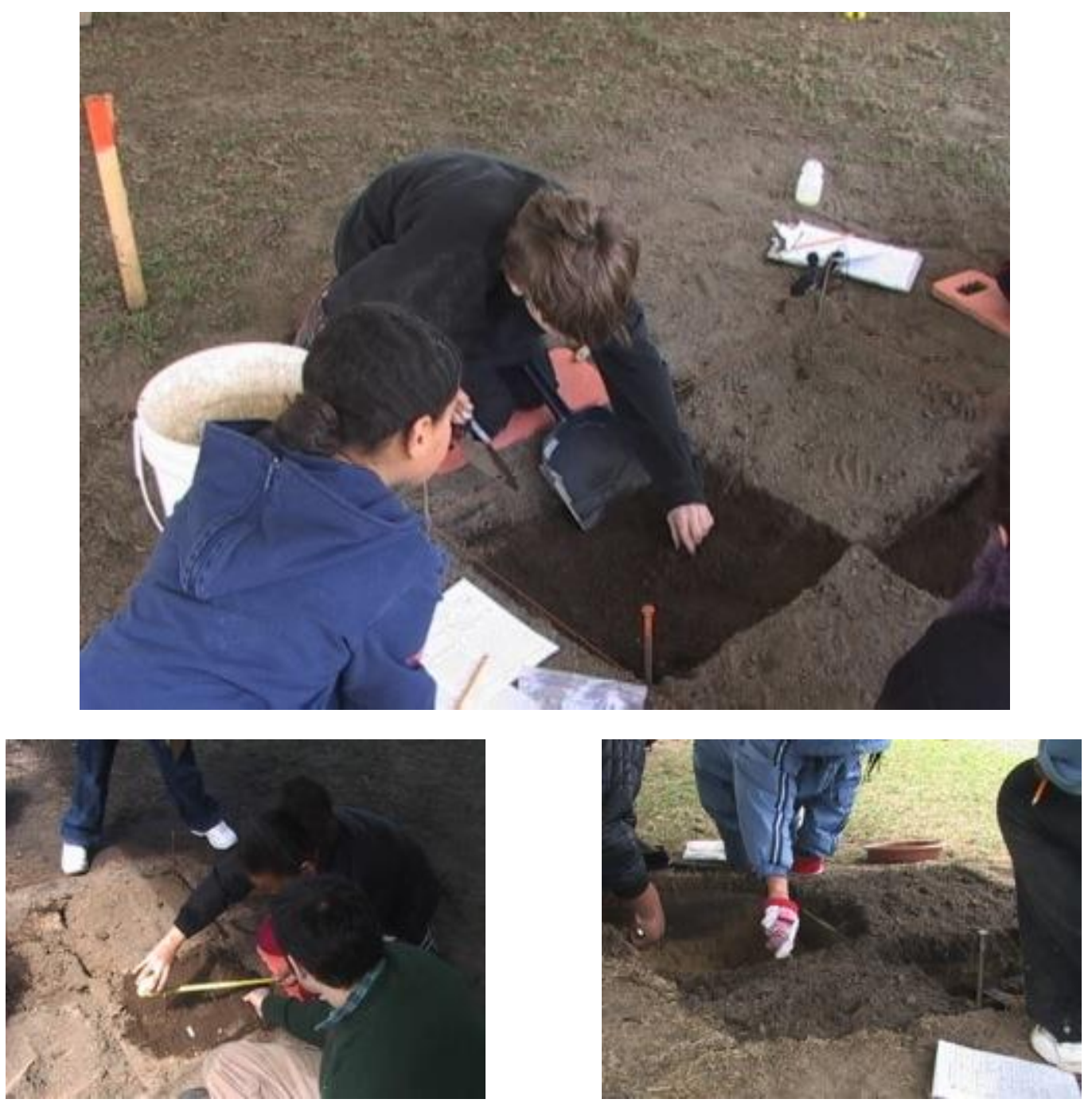

Figure 3. Archaeology Mock Excavation at the Museum

Like Mary, Colette also struggled with the offer of preconceived projects by SMSP. Colette noted that the projects were not equally open-ended. Some projects left more room to be transformed in ways meaningful to students than others. These more open-ended projects built upon students' interests and strengths. Colette pursued a project in archaeology the first year of our study (Figure 3). She also engaged in the art and science project Arrimage, which centered 
on the theme "Between the Earth and the Sky" the following year (Figure 4). Colette sought out the archaeology project since she wanted to explore Egypt with her students that year and felt the two themes would be quite complementary and bring history to life in ways more meaningful to students than teaching from books.
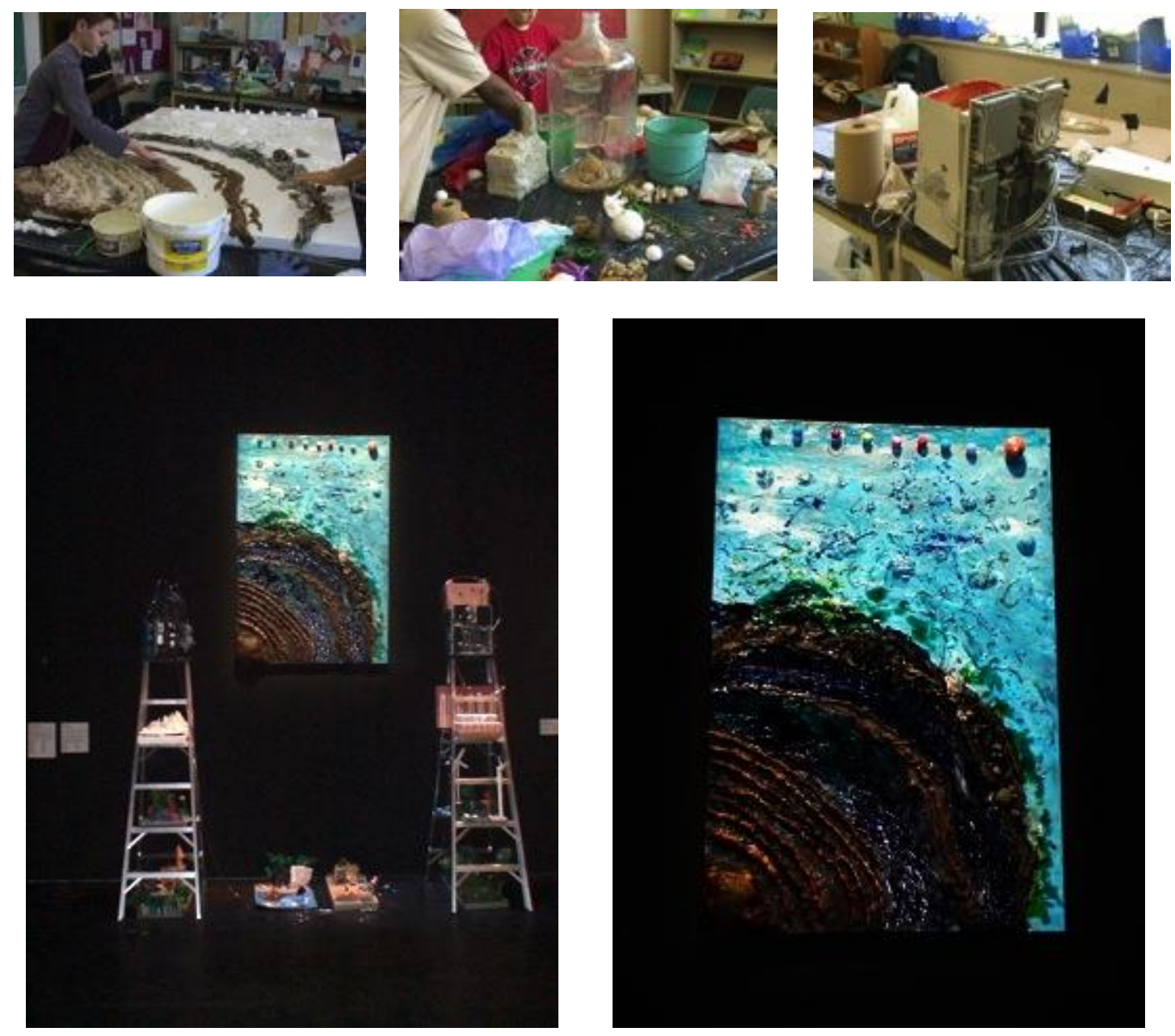

Figure 4. Arrimage Project and Exhibit in the Arts Museum

However, for Colette, visiting a museum was not simply to explore history. It was also a means to make cultural institutions more accessible to her students and "to get out of the school" (Interview, 2005). Colette was well aware that her students needed opportunities like this. She stated, "it is like opening a world to the students" (Interview, 2005). Realizing just how much her 
students enjoyed the museum full of archaeological artefacts made it clear to her "just how little my students get out even though they are interested in culture" (Interview, 2005). She was surprised about "their level of attention, their questions and their observations" (Interview, 2005) in the museum.

Colette, like Mary, strongly believed that "teaching comes from the child, the child that is ready to listen, who wants to learn, a child has interests, we have to be able to respond to that" (Interview, 2006). She also felt strongly that projects such as the ones SMPS offered were stimulating for her students, "making them live positive learning experiences, making them feel like they have contributions to make, which in the end, will help them stay in school and understand the school's relevance to their lives" (Interview, 2006). Both teachers emphasized in somewhat different ways how project-based learning can bring students in contact with community resources, such as museums and informal educators, thereby make learning locally relevant and student interest-driven, which helps rebuild students' self-esteem.

The particular museum-school partnerships, grounded in project-based learning, were understood to be a crucial means to demistify the arts and the sciences and to make evident to students the relevance of these disciplines to their own lives. For instance, in the context of the Arrimage project, Colette noted that:

...the project made evident that even artists are concerned about nature and pollution. They integrated plants in their artwork, so it was interesting for my students to see an artist who works not just with paint, that it goes further than that. (Interview, 2006)

Similarly, the science texts they read on climate change in conjunction with the art project were fictional, which made evident to the students that writers too engage with science but in ways somewhat different from scientists. As noted by Colette, "it supported learning about science not 
simply through the sciences but through literature and the arts" (Interview, 2006). Colette was finishing a Masters in Fine Arts at the time of the study, which coloured her engagement with her students.

Like Mary, Colette emphasized, "I love children, children are special and if we are willing to listen, there are so many things we can do, they already know so many things, but we have to listen" (Interview, 2006). In many ways, the SMSP's pre-designed museum-school partnership projects did not sufficiently "listen" to children and build on what they knew. It was up to Colette and Mary and the collaborating educators to make the projects further align with students' interests. They achieved this by letting students assume greater ownership over the projects over time. To this effect, Mary stated, "my students were allowed to play with aïbo during exhibit days...the educator left them with aïbo in their hand and knew they would not break it...that was amazing, they still talk about that" [Interview, 2005]. Mary felt that such an action on the part of one informal educator helped her students see themselves not simply as "victims of their neighborhood, but as capable" (Interview, 2005) and in the centre of the project.

\section{Project-based museum-school partnerships: Next steps}

Teachers who are committed to project-based learning, such as Mary and Colette, may be more inclined to seek out learning settings outside of their classrooms to enrich and support student learning (Adams \& Gupta, 2015). The project-based musem-school partnerships featured in this article were open-ended, enabling the projects to be transformed in ways meaningful to students and driven by their interests. The four museum-school partnership projects also offered a means for all participants (students, teachers, artists, scientists, archaeologists, and informal educators) to engage in cross-setting learning and made additional resources accessible to them in meaningful ways. 
The study also hints at the importance of including activities that are co-designed by teachers, students, artists, scientists, archaeologists, and informal educators (Katz et al., 2013; Weiland \& Akerson, 2013). To design together and work with the partners could make such projects student interest-driven and empowering to all involved (Lemonchois, 2015). This is an area in need of further development. The efforts regarding this should begin in teacher education programs. Student teachers could be encouraged to pursue an internship in an informal educational setting in addition to classroom settings to experience cross-setting learning firsthand (Adams \& Gupta, 2015; Dionne \& Deblois, 2011; Wallace, 2013). Pre-service projects and professional development centering on the co-design of activities with museums and youth would be another venue to pursue (Luehmann \& Markowitz, 2007). These efforts would move us closer to the development of more equitable learning ecologies that are inclusive of all students and supportive of student interest-driven learning, empowerement, and agency.

\section{References}

Adams, J. D., \& Gupta (2015). Informal science institutions and learning to teach: An examination of identity, agency, and affordances. Journal of Research in Science Teaching. Retrieved from: http://onlinelibrary.wiley.com/doi/10.1002/tea.21270/abstract

American Alliance of Museum (2014). Building the future of education: Museums and the learning ecosystem. Washington, DC: American Alliance of Museum.

Archambault, J., \& Richer, C. (2014). Leadership for social justice through fifteen years of intervention in a disadvantaged and multicultural Canadian urban area: The Supporting Montréal Schools Program. In L. Bogotch \& C. M. Shields (Eds.), International Handbook of Educational Leadership and Social (In)Justice, Vol. 29 (pp. 1023-1046). New York, NY: Springer. 
Banks, J. A., Au, K. H., Ball, A. F., Bell, P. A., Gordon, E. W., Gutiérrez, K. D., Heath, S. B., Lee, C. D., Lee, Y., Mahiri, J., Nasir, N. S., Valdés, G., \& Zhou, M. (2007). Learning in and out of school in diverse environments: Life-long, life-wide, life-deep. Seattle, Washington: Center for Multicultural Education, University of Washington.

Bevan, B., \& Dillon, J. (2010). Broadening views of learning: Developing educators for the 21st Century through an international research partnership at the Exploratorium and King's College London. The New Educator, 6(3-4), 167-180.

Dionne, L. \& Deblois, A. (2011). Un partenariat muséal pour améliorer la préparation en sciences chez de futurs enseignants. In G. Samson, A. Hasni, A., D. Gauthier, \& P. Potvin, (Eds.), Pour une collaboration école-université en science et techno: des pistes pour l'apprentissage (pp. 117-130). Sainte-Foy, QC: Presses Université du Québec.

Katz, P., McGinnis, J. R., Riedinger, K., Marbach-Ad, G., \& Dai, A. (2013). The influence of informal science education experiences on the development of two beginning teachers' science classroom teaching identity. Journal of Science Teacher Education, 24, 13571379.

Kisiel, J. (2014). Clarifying the complexities of school-museum interactions: Perspectives from two communities. Journal of Research in Science Teaching, 51(3), 342-367.

Lemonchois, M. (2015). La participation à des projets artistiques, vecteur d'émancipation? Le Cas de projet de creation dans des écoles montréalaises en milieu défavorisé. Culture \& Musées, 26, 159-178.

Lemonchois, M. (2010). Quelle est la participation des élèves lors d'interventions d'artistes dans des écoles primaires? Encounters on Education, 11(Fall), 99-114. 
Luehmann, A. L., \& Markowitz, D. (2007). Science teachers' perceived benefits of an out-ofschool enrichment programme: Identity needs and university affordances. International Journal of Science Education, 29(9), 1133-1161.

Ministry of Education of Québec (MEQ) (2004). Description of Supporting Montreal School Program. Unpublished document.

Rahm, J. (2006). A look at meaning making in science through School-Scientist-Museum Partnerships. The Canadian Journal of Science, Mathematics and Technology Education (Special Issue on Informal Science Education), 6(1), 47-66.

Rahm, J. (2008). "It made us learn so much more about science!“" How innovative partnership projects among schools, museums, and scientists can make science museums accessible to poor inner-city youth. In A. Meunier \& A. Landry (Eds.), Research in museum education: Actions and perspectives (pp. 117-141). Sainte-Foy, QC: Multimondes.

Rahm, J. (2012). Activity theory as a lens to examine project-based museum partnerships in robotics. In E. Davidsson \& A. Jakobsson (Eds.), Understanding interactions at science centers and museums (pp. 147-171). Rotterdam, Netherlands: Sense.

Russell, J., Knutson, K., \& Crowley, K. (2013). Informal learning organizations as part of an educational ecology: Lessons from collaboration across the formal/informal divide. Journal of Educational Change 14(3), 259-281.

Weiland, I. S., \& Akerson, V. L. (2013). Toward understanding the nature of a partnership between an elementary classroom teacher and an informal science educator. Journal of Science Teacher Education, 24, 1333-1355. 